\title{
PHYTOSEIID MITES (ACARINA) OF NORTHEASTERN BRAZIL WITH DESCRIPTIONS OF FOUR NEW SPECIES
}

\author{
Gilberto J. de Moraes ${ }^{1}$ and James A. McMurtry ${ }^{2}$ \\ 1. Centro Pesquisa Agropecuaria do Tropico Semi-Arido/Empresa Brasileira Pesquisa Agropecuaria, 56.300 - \\ Petrolina-PE-Brazil and 2. Division of Biological Control, Department of Entomology, \\ University of California, Riverside, CA 92521, U.S.A.
}

\begin{abstract}
This paper reports the occurrence of 21 species of Phytoseiidae in northeastern Brazil, 4 of which are new: Amblyseius paraibensis, Euseius unisetus, Typhlodromus paraevectus and Phytoseius pernambucanus n. spp.
\end{abstract}

RESUMO-ACAROS FITOSEIDEOS (ACARINA) DO NORDESTE DO BRASIL E DESCRICOES DE QUATRO ESPECIES NOVAS. Este trabalho relata a ocorrencia de 21 especies de Phytoseiidae no nordeste do Brasil, 4 das quais sao especies novas: Amblyseius paraibensis, Euseius unisetus, Typhlodromus paraevectus e Phytoseius pernambucanus spp. n.

\section{INTRODUCTION}

Mites of the family Phytoseiidae have been recognized as important predators of phytophagous mites, mostly of those belonging to the family Tetranychidae. Only a few papers have reported on the occurrence and distribution of Phytoseiidae in Brazil. Ehara (1966) was the first author to survey these mites in that country, referring to eight species in the state of Sao Paulo. Denmark and Muma (1970a) redescribed Ricoseius loxocheles (DeLeon) from Brazil. Denmark and Muma (1973) reported 55 species, mostly from southern Brazil, 17 of which were considered new. Elbanhawy $(1975,1976,1978)$ described new species of Phytoseiidae from Sao Paulo, Brazil.

Farias et al. (1981) listed 6 phytoseiids associated with the green cassava mite, Mononychellus tanajoa (Bondar), on cassava, in the northeast. Moraes and Oliveira (1982) reported the occurrence of 7 phytoseiid species in coastal Pernambuco, in northeastern Brazil.

The present paper is concerned with the phytoseiids found in the semi-arid tropics of northeastern Brazil, from August 1978 to August 1980, in association with cultivated and wild plant species.

Only original descriptions and important synonyms are cited.

Depositories of the new species are abbreviated: CPATSA/EMBPAPA (Centro de Pesquisa Agropecuaria do Tropico Semi-Arido/Empresa Brasileira de Pesquisa Agropecuaria, 56.300-Petrolina-PE, Brasil); UCR (University of California, Riverside, CA, U.S.A. 92521); USNM (United States National Museum, Washington, DC, U.S.A.). 
All the measurements are given in micra.

The generic concepts adopted in this paper generally follow those of Chant (1965). However, based on recent investigations conducted by the second author (McMurtry, 1983), Euseius Wainstein is considered a valid genus. The dorsal setal nomenclature is based on that proposed by Rowell et al. (1978).

\section{Amblyseius aripo (DeLeon)}

Typhlodromalus aripo DeLeon, 1967:21; Denmark and Muma, 1973:257

The average measurements of 10 adult females collected and, in parentheses, the corresponding measurements from the original description are: dorsal shield length 324 (338), width $193(194), \mathrm{j}_{1} 28(26), \mathrm{j}_{3} 38(35)$, j4 12 (14), j5 12 (not given), j6 16 (not given), J2 16 (21), J5 6 (not given), z2 17 (16), z4 34 (29), z5 11 (14), $Z_{1} 20$ (29), $\mathrm{Z}_{4} 57$ (47), $\mathrm{Z}_{5} 75$ (56), s4 50 (42), S2 31 (29), S4 24 (27), S5 12 (10), r 322 (not given), R 17 (not given), SgeIV 46 (44), $\mathrm{S}_{\text {tiIV }} 20(27), \mathrm{S}_{\mathrm{tIV}} 72(61)$.

Records: Petrolina-Pernambuco, November 1978 and May 1980, on Lycopersicum esculentum; Barreiras-Bahia, January 1979, on Gossypium sp. and Blainvillea sp.; Xique-Xique-Bahia, March 1979, on Gossypium sp:

On unsprayed tomato, A. aripo was commonly found associated with Aculops lycopersici (Massee) (Eriophyidae).

Previous records: Trinidad-Tobago (DeLeon, 1967), Brazil (Denmark \& Muma, 1973), Jamaica (Denmark \& Muma, 1978) and El Salvador (Denmark \& Andrews, 1981).

\section{Amblyseius limonicus Garman \& McGregor}

Amblyseius limonicus Garman \& McGregor, 1956:11; Schuster \& Pritchard, 1963:227; Chant \& Baker, 1965:22 Typhlodromus (Amblyseius) limonicus, Chant, 1959:96

Typhlodromalus limonicus, Muma et al., 1970:90; Farias et al., 1981:316

The specimens collected are similar to those found in California, as redescribed by Schuster \& Pritchard (1963), except for the shorter j3, s4 and $Z_{5}$.

For comparison, the measurements of 2 adult females collected and, in parentheses, the corresponding measurements of California specimens (Schuster \& Pritchard, 1963), are given: dorsal shield length 366 (375), width 234 (260), j1 30 (34), j3 37 (50), j4 9 (8), j5 10 (8), j6 11 (8), J2 14 (10), J5 10 (8), z2 13 (10), z4 14 (10), z5 10 (8), $Z_{1} 15(10), Z_{4} 15$ (10), Z5 53 (62), s4 41 (72), S2 18 (14), S4 15 (14), S5 14 (11), r3 15 (17), R 11 (8), SgeIV 66 (80), S $\mathrm{S}_{\mathrm{tiIV}} 49$ (62), S $\mathrm{tIV} 94$ (105). Considering the discussion presented by McMurtry (1983), it seems that the Brazil specimens are very similar to $A$. limonicus found in Chapol and Chicacao (Guatemala).

Record: Miguel Calmon-Bahia, February 1979, on Manihot sp.

Previous records: U.S.A (Garman \& McGregor, 1956; Schuster \& Pritchard, 1963; Muma et al., 1970), Mexico (DeLeon, 1961), New Zealand (Collyer, 1964), Nicaragua, Honduras (Chant \& Baker, 1965), Hawaii (Prasad, 1968), Puerto Rico (Denmark \& Muma, 1975), Jamaica (Denmark \& Muma, 1978), Brazil (Farias et al., 1981), Colombia (Moraes et al., 1982) and Guatemala (McMurtry, 1983).

$$
\text { Amblyseius cannaensis (Muma) }
$$

Amblyseiulus cánnaensis Muma, 1962:4

Proprioseiopsis cannaensis, Muma et al., 1970:38; Denmark \& Andrews, 1981:148 

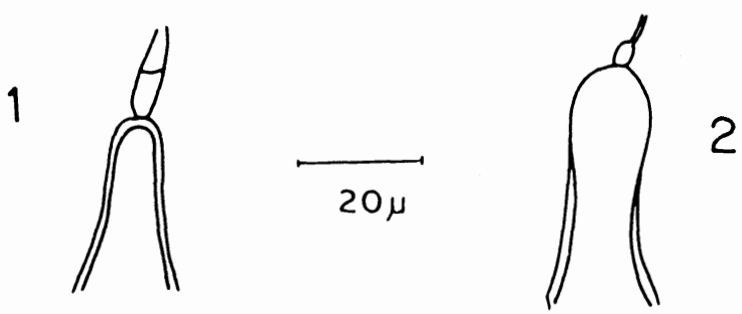

Fig. 1-2-Spermathecae of holotypes, 1 - Amblyseius cannaensis; 2 - Amblyseius ovatus.

This species was found in just one location which differs considerably from other areas visited in having very mild climatic conditions. The average annual rainfall in this area is about $726 \mathrm{~mm}$.

A. cannaensis is very similar to Amblyseius ovatus (Garman). However, it can be distinguished from that species by the shorter dorsal shield and macrosetae of leg IV. Furthermore, the spermatheca of $A$. cannaensis is shorter and increases progressively in diameter towards the base (Figure 1). The spermatheca of $A$. ovatus is somewhat constricted in the middle (Figure 2). Table I shows the average measurements of both species.

TABLE 1-Comparative measurements of the holotype of $A$. cannaensis, of the Brazilian specimens of $A$. cannaensis, and of the holotype of the closely related species, $A$. ovatus.

\begin{tabular}{|c|c|c|c|}
\hline & $\begin{array}{c}\text { A. cannaensis } \\
\text { (holotype) }\end{array}$ & $\begin{array}{l}\text { A. } \text { cannaensis* }^{*} \\
\text { (coll. this study) }\end{array}$ & $\begin{array}{l}\text { A. ovatus } \\
\text { (holotype) }\end{array}$ \\
\hline Dorsal shield length & 322 & 322 & 372 \\
\hline Dorsal shield width & 252 & 226 & 252 \\
\hline $\mathrm{j}_{1}$ & 28 & 28 & 28 \\
\hline $\mathrm{j} 3$ & 62 & 59 & 64 \\
\hline $\mathrm{j} 4$ & $?$ & 5 & 8 \\
\hline j5 & 5 & 5 & 8 \\
\hline $\mathrm{j} 6$ & 10 & 9 & 12 \\
\hline $\mathrm{J}_{5}$ & 4 & 7 & 8 \\
\hline $\mathrm{z} 2$ & 36 & 35 & 42 \\
\hline $\mathrm{z} 4$ & 23 & 24 & 22 \\
\hline $\mathrm{z} 5$ & 6 & 6 & 8 \\
\hline $\mathrm{Z}_{1}$ & 25 & 24 & 17 \\
\hline $\mathrm{Z}_{4}$ & 115 & 106 & 101 \\
\hline$Z_{5}$ & 85 & 84 & 90 \\
\hline s4 & 100 & 95 & 88 \\
\hline $\mathrm{S}_{2}$ & 23 & 23 & 17 \\
\hline $\mathrm{S}_{4}$ & 23 & 12 & 16 \\
\hline $\mathrm{S}_{5}$ & 12 & 10 & 12 \\
\hline r3 & 19 & 17 & 22 \\
\hline $\mathrm{R}_{1}$ & 12 & 11 & 17 \\
\hline SgeIV & 48 & 40 & 55 \\
\hline $\mathrm{S}_{\mathrm{tiIV}}$ & 35 & 27 & 43 \\
\hline $\mathrm{S}_{\mathrm{tIV}}$ & 77 & 65 & 96 \\
\hline Sperm. cervix length & 13 & 14 & 22 \\
\hline
\end{tabular}

*Average of 3 females. 
Records: Morro do Chapeu, Bahia, February 1979, on Capsicum sp.

Previous records: USA (Muma, 1962; Muma et al., 1970) and El Salvador (Denmark \& Andrews, 1981).

$$
\text { Amblyseius mexicanus (Garman) }
$$

Amblyseiopsis mexicanus Garman, 1958:75

Proprioseiopsis mexicanus, Muma et al., 1970:48; Denmark \& Muma, 1973:237

Just one individual of this species was collected. No data about setal lengths for this species were found in the literature. The measurements of the specimen collected are given, followed, in parentheses, by the measurements of the holotype: dorsal shield length 340 (355), width 235 (216), j1 19 (22), j3 29 (28), j4 6 (6), j5 6 (5), j6 6 (7), J5 8 (7), z2 14 (14), z4 10 (10), z5 5 (5), Z 6 (6), Z4 73 (73), Z5 103 (98), s4 55 (56), S2 9 (8), S4 9 (8), S5 8 (8), r3 14 (13), R 19 (7), SgeIV 46 (54), StiIV 31 (32), StIV 59 (62).

Record: Sousa-Paraiba, March 1979, on Vigna unguiculata.

This species is commonly found in litter of different plant species. Perhaps the fact that no litter samples were examined in this study explains the rarity of this species in our collections. The single specimen taken was on a low growing plant, in a region where the average annual rainfall is about $727 \mathrm{~mm}$.

Previous records: Mexico (Garman, 1958), U.S.A. (Chant, 1959; Muma et al., 1967; Specht, 1968; Muma et al., 1970), New Zealand (Collyer, 1964). Hawaii (Prasad, 1968) and Brazil (Denmark \& Muma, 1973).

\section{Amblyseius sp. near compositus Denmark \& Muma}

Amblyseius compositus Denmark \& Muma, 1973:240

The only individual found seems to be close to $A$. compositus, except for the longer $\mathrm{j} 3$ (51), $\mathrm{S}_{2}$ (13), $\mathrm{S}_{5}$ (14) and $\mathrm{Z}_{5}(160)$. According to the original description, the lengths of these setae are 35, 6, 6 and $104 \mathrm{uu}$, respectively. This mite was found during the wet season, in an area where irrigation is available throughout the year and where the average annual rainfall is about $573 \mathrm{~mm}$.

Record: Irece-Bahia, February 1979, on Psidium guajava.

Previous record of A. compositus: Brazil (Denmark \& Muma, 1973).

$$
\text { Amblyseius idaeus (Denmark \& Muma) }
$$

Neoseiulus idaeus Denmark \& Muma, 1973:266

A. idaeus was the second most common species found in this study. It was the most frequent species in association with mites of the family Tetranychidae. The specimens collected agree well with the original description of the species, except for setal formula of Genu III, which in the individuals collected is $1-2 / 1-$ $2 / 0-1(1-2-2 / 0-1$ given in original description). The examination of a paratype from Piracicaba-Sao Paulo showed the same setal formula as the individuals collected in this study.

The average measurements of 10 adult females and, in parentheses, the corresponding measurements from the original description of the species are: dorsal shield length 332 (322), width 163 (158), j1 23 (19), j3 48 (44), j4 44 (40), j5 44 (42), j6 52 (50), J2 53 (49), J5 10 (11), z2 45 (42), z4 52 (52), z5 37 (36), Z 54 (50), Z4 66 (62), Z5 72 (62), s4 62 (62), S 60 (55), S4 33 (30), S5 27 (26), r3 30 (29), R 131 (32), StIV 42 (42).

Records: Petrolina-Pernambuco, September, October and November 1978, and January, November and December 1979, on Phaseolus vulgaris, Ricinus communis, Amaranthus sp., Jatropha gossypifolia, Ipomoea fistulosa, Citrus sp., Manihot pseudoglaziokii, Carica papaya, Cucumis melo, Lycopersicum esculentum, 
Citrullus vulgaris and Passiflora edulis; Petrolandia-Pernambuco, November 1978, on Tagetes sp.; Belem do Sao Francisco-Pernambuco, November 1978, on P. vulgaris, R. communis and Gossypium sp.; Sousa-Paraiba, January and November 1979, on Musa cavendish, Vigna unguiculata, Manihot sp. and Cucurbita sp.; IreceBahia, February 1979, on J. gossypifolia and unknown Malvaceae; Santa Maria da Boa Vista-Pernambuco, November 1979, on J. gossypifolia; Sento Se-Bahia, January and February 1980, on Zea mays, P. vulgaris, Jatropha sp. and Capsicum annuum; Fortaleza-Ceara, December 1979, on Manihot glaziokii; AraripinaPernambuco, February 1980, on Manihot sp.; Juazeiro-Bahia, February 1980, on Jatropha sp.; OuricuriPernambuco, April 1980, on Tagetes sp.

A. idaeus was found associated with Tetranychus desertorum Banks, Tetranychus neocaledonicus Andre, Tetranychus bastosi Tuttle, Baker \& Sales, Tetranychus ludeni Zacher, Tetranychus cinnabarinus (Boisduval), Tetranychus mexicanus (McGregor), Mononychellus tanajoa (Bondar), Tetranychus evansi Baker \& Pritchard, Oligonychus zeae (McGregor)(Tetranychidae) and Brevipalpus phoenicis (Geijskes) (Tenuipalpidae). It was found associated with Tetranychidae in $71 \%$ of the collections and the species was either T. bastosi or $T$. desertorum in $37 \%$ of the cases. This common species was found under humid as well as under very dry conditions.

Previous records: Brazil (Denmark \& Muma, 1973; Farias et al., 1981).

\section{Amblyseius mumai (Denmark)}

Cydnodromus mumai Denmark, 1965:91

Neoseiulus mumai, Muma et al., 1970:110

Amblyseius mumai, Schicha, 1981:209

To date, this species has been reported only from Florida and Arizona, U.S.A. It was found just once in our collections, but in large numbers. The individuals are flattened; this seems to be an adaptation to inhabiting the bases of monocotyledoneous hosts. Muma et al. (1970) referred to the common association of this species, as well as the closely related Amblyseius paspalivorous, with palms and grasses.

The average measurements of 8 adult females from Brazil and, in parentheses, the corresponding measurements of the female holotype, according to Schicha (1981), are given: dorsal shield length 358 (355), width 151 (152), j1 16 (18), j3 14 (13), j4 9 (10), j5 10 (11), j6 12 (broken off on holotype), J 12 (12), J5 9 (10), z2 $11(12), z_{4} 12$ (15), z5 9 (12), $Z_{1} 11(13), Z_{4} 19$ (22), Z 53 (65), s4 15 (16), S2 14 (16), S4 16 (21), S5 21 (25), r3 15 (15), $\mathrm{R}_{1} 13$ (13), $\mathrm{S}_{\mathrm{t}} \mathrm{IV} 26$ (39).

Record: Petrolina-Pernambuco, August 1980, on Allium sativum L. It was found associated with Eriophyes tulipae Keifer and Steneotarsonemus sp. near furcatus DeLeon, under rather humid conditions.

Previous records: U.S.A. (Denmark, 1965; Muma et al., 1970; Tuttle \& Muma, 1973).

$$
\text { Amblyseius transversus (Denmark \& Muma) }
$$

Neoseiulus transversus Denmark \& Muma, 1973:267

The only individual found fits the description of $A$. transversus, except for $\mathrm{j} 4$ being the same length as j5 (16). It should be noted, however, that the drawing of Denmark \& Muma (1973) actually shows j4 of approximately the same size as j5, although in the description the lengths of $\mathrm{j}_{4}$ and $\mathrm{j} 5$ are 31 and $14 \mathrm{uu}$, respectively.

Record: Sousa-Paraiba, January 1979, on Rhyncosia minima.

This mite was found associated with Mononychellus planki (McGregor) (Tetranychidae).

Previous record: Brazil (Denmark \& Muma, 1973).

Amblyseius paraibensis Moraes and McMurtry, n.sp.

(Figs. 3-10) 


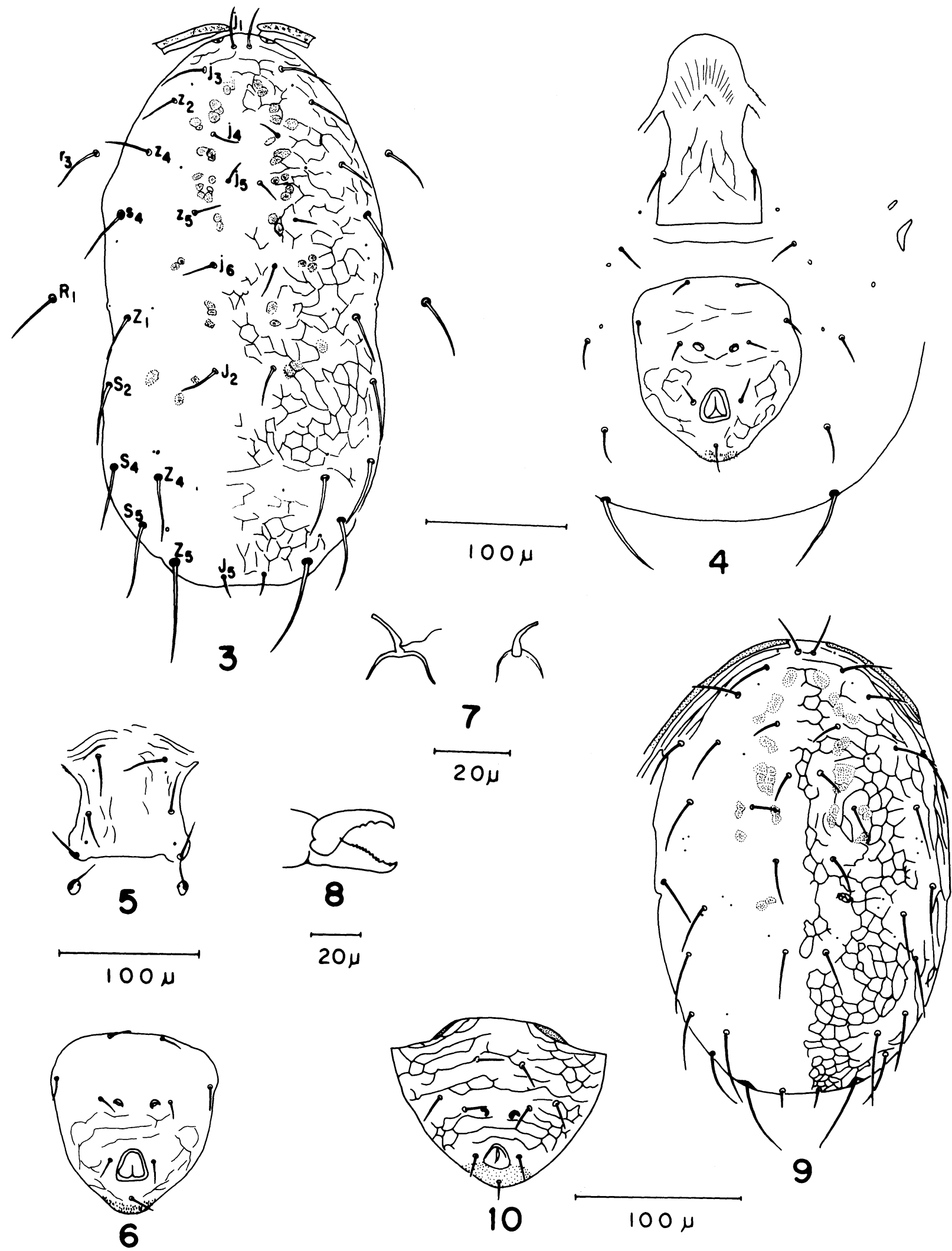

Fig. 3-10-Amblyseius paraibensis n. sp., 3 - female dorsal shield; 4 - female posterior ventral surface; 5 - female sternal shield; 6 - female ventrianal shield; 7 - spermathecae; 8 - female chelicera; 9 - male dorsal shield; 10 - male ventrianal shield. 
DIAGNOSIS-This species differs from Amblyseius californicus (McGregor) and Amblyseius chilenensis (Dosse) by the larger number of teeth on the fixed digit of chelicera, by the longer macrosetae of leg IV and the subquadrate ventrianal shield. Amblyseius comitatus (DeLeon) also resembles $A$. paraibensis, but differs in having only 6 teeth on the fixed digit. A. paraibensis differs from all those species by having all the dorsal shield setae smooth. It is similar to Amblyseius imbricatus Corpuz \& Rimando, but has shorter dorsal shield setae.

FEMALE-Dorsal shield imbricate, with 13 pairs of pores. The average measurements (and ranges) of 6 adults are: dorsal shield length 382 (355-394), width 197 (187-204), j1 29 (29-30), j3 39 (37-42), j4 20 (18-22), j5 20 (19-22), j6 27 (24-29), J2 34 (31-36), J5 15 (14-16), z2 33 (30-35), z4 35 (34-36), z5 21 (19-24), Z1 35 (32-36), Z4 48 (47-50), Z 70 (62-73), s4 46 (42-48), S2 45 (43-47), S4 49 (44-54), S5 51 (48-54), r3 40 (38-4 1), R 141 (38-47), SgeIV $30(30-31), S_{\text {tiIV }} 30$ (30-36), StIV 69 (62-72). All dorsal shield setae and macrosetae smooth and setaceous. Sternal shield striated, with 3 pairs of setae and 2 pairs of pores. Metasternal setae on platelets. Genital shield faintly striated. Ventrianal shield striated, subquadrate, length 124 (120-126), largest width 116 (108-120); 3 pairs of preanal setae and a pair of large pores. Ge II $2-2-2 / 0-1$; GeIII $1-2 / 1-2 / 0-1$. Spermatheca cup-shaped. Fixed digit of chelicera with at least 10 teeth; movable digit with 3 teeth. Each digit 34 uu long.

MALE-Dorsal shield imbricate. The measurements of one male are as follows: dorsal shield length 276, width $187, \mathrm{j}_{1} 23, \mathrm{j} 331, \mathrm{j} 418, \mathrm{j} 5$ 18, j6 26, J2 26, J5 8, z2 30, z4 28, z5 20, $\mathrm{Z}_{1} 31, \mathrm{Z}_{4} 48, \mathrm{Z}_{5} 48$, s4 35, S2 38, S4 37, $\mathrm{S}_{5} 36, \mathrm{r}_{3} 34, \mathrm{R}_{1} 31$, S SeIV 25 , StiIV 28 , S SIV 50 . Ventrianal shield imbricate, length 102, greatest width 130, with 4 pairs of preanal setae and a pair of pores.

LOCALITY AND TYPE MATERIAL-Holotype-female, from Musa sp., Sousa-Paraiba, November 28, 1979 (G. J. Moraes), deposited in CPATSA/EMBRAPA.

Allotype-male, from Oriza sativa, Sousa-Paraiba, May 20, 1980 (G. J. Moraes), deposited in C P A T S A / EMBRAPA.

Paratypes-3 females, same data as holotype, and 2 females, same data as allotype, deposited in CPATSA/EMBRAPA, UCR and USNM.

\section{Euseius alatus DeLeon}

Euseius alatus DeLeon, 1966:87; Denmark \& Muma, 1973:262

Euseius paraguayensis Denmark \& Muma, 1970b:224; 1972:21 and 1973:262 (New Synonymy).

Some consistent differences between the individuals collected and those from Guiana are the smaller size of the dorsal shield and the shorter $\mathrm{S}_{2}, \mathrm{~S}_{4}, \mathrm{~S}_{5}, \mathrm{Z}_{5}$ and $\mathrm{S}_{\mathrm{geIV}}$.

The average measurements of 11 individuals collected are given, followed in parentheses, by the measurements given in the original description of the species: dorsal shield length 312 (325), width $223(260), \mathrm{j}_{1} 26(28)$, j3 21 (21), j4 15 (not given), j5 15 (16), j6 17 (not given), $\mathrm{J}_{2} 18$ (20), $\mathrm{J}_{5} 5$ (not given), $\mathrm{z}_{2} 18$ (17), z4 20 (20), z5 15 (not given), $Z_{1} 17$ (21), $Z_{4} 20$ (22), $Z_{5} 57$ (63), s4 25 (26), $S_{2} 21$ (25), $S_{4} 22$ (28), $S_{5} 21$ (28), $r_{3} 15$ (not given), $R_{1} 13$ (not given), S $\mathrm{geIV}_{38}(48), \mathrm{S}_{\mathrm{tiIV}} 26$ (28), S $\mathrm{tIV} 48$ (53). All the individuals collected have sharp-tipped $\mathrm{S}_{\mathrm{geIi}}$, except for

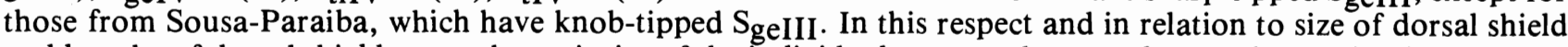
and lengths of dorsal shield setae, the majority of the individuals seem to be very close to the species described by Denmark \& Muma as Euseius paraguayensis and herein synonymized with $A$. alatus.

On the other hand, it should be noted that the position of $R_{1}$ is variable among individuals of a population or even in the same individual (right and left side). This seta may occur either on the dorsal shield or on the interscutal membrane, whereas the original description stated that it was on the dorsal shield (DeLeon, 1966).

Records: Sousa-Paraiba, November 1978 and November 1979, on Mangifera indica; Miguel CalmonBahia, February 1979, on Citrus sp.; Araripina-Pernambuco, February 1980, on M. indica, Anacardium occidentale and Citrus sp.; Exu-Pernambuco, March 1980, on Jatropha sp.; Pindobacu-Bahia, March 1980, on Citrus sp.; Saude-Bahia, March 1980, on Solanum sp.; Ipubi-Pernambuco, April 1980, on Coffea sp., A. occidentale and Sida sp.; Crato-Ceara, March 1980, on A. occidentale. 
Except for one case, this mite was found only on leaves with smooth surfaces. When on $M$. indica, the mite was associated with Oligonychus mangiferus Rahman \& Punjab (Tetranychidae). This species was found only in relatively wet areas of the semi-arid tropics, where the average annual rain fall was between $700-1300 \mathrm{~mm}$.

Previous records: Guiana (DeLeon, 1966), Paraguay (Denmark \& Muma, 1970b), Colombia (Denmark \& Muma, 1972) and Brazil (Denmark \& Muma, 1973).

\section{Euseius citrifolius Denmark \& Muma}

Euseius citrifolius Denmark \& Muma, 1970b:222

On the average, the specimens from Brazil have longer $\mathrm{j}_{4}-\mathrm{j} 6, \mathrm{r}_{3}$ and $\mathrm{R}_{1}$ setae and shorter $\mathrm{j}_{1}$ and lateral setae and macrosetae of leg IV compared to the measurements given in the original description (Denmark \& Muma, 1970b).

The average measurements of 13 individuals collected are compared with the corresponding measurements in the original description (in parenthesis): dorsal shield length 315 (315), width 207 (223), j1 25 (28), j3 24 (30), j4 13 (7), j5 13 (8), j6 14 (8), J2 14 (8), J5 5 (5), z2 17 (20), z4 20 (21), z5 12 (13), Z1 14 (13), Z4 16 (17), Z 56 (64), s4 33 (39), S 17 (19), S4 18 (20), S 22 (27), r3 17 (11), R 13 (8), SgeIV 37 (47), StiIV 29 (34), StIV 53 (58). The measurements of a paratype from Coronel Oviedo-Paraguay agree very well with the measurements given above for the specimens collected in Brazil. Although in most cases $r_{3}$ and $R_{1}$ were on the interscutal membrane, these setae were on the dorsal shield in a few specimens.

Records: Petrolina-Pernambuco, October and November 1978 and October and November 1979, on L. esculentum, Solanum nigrum, Citrus sp., P. guajava and Vitis vinifera; Petrolandia-Pernambuco, November 1978, on C. papaya and P. guajava; Belem do Sao Francisco-Pernambuco, November 1978, on Citrus sp.; SousaParaiba, January, March and November 1979 and May 1980, on Gossypium sp.; P. guajava, C. papaya, Terminalia catappa, Manihot sp., Persea sp., Citrus sp., unknown Gramineae, Cassia sp. and unknown Leguminosae; Barreiras-Bahia, January 1979, on P. guajava; Xique-Xique-Bahia, March 1979, on Z. mays; Ouricuri-Pernambuco, January 1980, on Phytolacca dioica, P. guajava and Malpighia punicifolia; Brejo SantoCeara, January 1980, on $A$. occidentale; Parnamirim-Pernambuco, January 1980, on P. dioica; AraripinaPernambuco, January 1980, on Anona squamosa; Pindobacu-Bahia, March 1980, on Citrus sp.; TrindadePernambuco, January 1980, on Citrus sp.

This mite was found associated with Tetranychus evansi, Tetranychus mexicanus, Tetranychus bastosi, Eutetranychus banksi (McGregor), Mononychellus planki (Tetranychidae) and Brevipalpus phoenicis. In $40 \%$ of the collections, E. citrifolius was found in association with the phytoseiid Euseius concordis (Chant).

Previous records: Paraguay (Denmark \& Muma, 1970b) and Brazil (McMurtry, unpublished).

\section{Euseius concordis (Chant)}

Typhlodromus (Amblyseius) concordis Chant, 1959:69

Amblyseius concordis, Chant \& Baker, 1965:22

Euseius flechtmanni Denmark \& Muma, 1970b:223 and 1973:261; (synonymy, according to Moraes et al., 1982:18)

Euseius concordis, Denmark \& Muma, 1973:264; Moraes \& Oliveira, 1982:317

This was by far the most common phytoseiid in the areas visited.

Contrary to the original description (Chant, 1959), Chant and Baker (1965) stated that $R_{1}$ was present and two, rather than one, pairs of metapodal shields were found in this species.

In the specimens collected, macrosetae were always present on gena of legs I to III (absent, according to Chant \& Baker, 1965; present on geII and III, according to Denmark \& Muma, 1970). Macrosetae of geIII are 
sharp-tipped, except for a few populations in which individuals with sharp- and knob-tipped SgeIII were observed. Macrosetae of leg IV are consistently knob-tipped. Denmark \& Muma (1970b) characterized $E$. concordis $(=E$. flechtmanni) from Paraguay as possessing knobbed bacillate SgeIII. The body and setal lengths of our specimens agree very well with those given by Denmark \& Muma (1970b).

The measurements of seven adult females collected and, in parentheses, the measurements of the holotype (according to McMurtry, 1983) are: dorsal shield length 300-340 (317), width 221-240 (230), j1 24-31 (30), j3 23-43 (37), j4 8-13 (10), j5 10-13 (9), j6 11-13 (13), J2 11-13 (broken), J5 5-6 (broken), z2 18-30 (17), z4 23-49 (29), z5 8-11 (9), $\mathrm{Z}_{1}$ 11-14 (11), Z4 11-16 (11), Z5 62-68 (64), s4 43-64 (52), S2 13-19 (14), S4 14-20 (16), S5 18-28 (18), $\mathrm{r}_{3}$ 16-23 (16), R 1 8-13 (missing), SgeIV 41-48 (41), StiIV 30-34 (27), StIV 50-56 (46).

Records: Petrolina-Pernambuco, September, October and November 1978, January, March and October 1979, on Ricinus communis, Citrus sp., Euphorbia geniculata, Lycopersicum esculentum, Solanum americanum, Psidium guajava, Anacardium occidentale, Manihot pseudoglaziokii, Anona muricata, Carica papaya, Rosa sp.; Petrolandia-Pernambuco, November 1978, on Rosa sp., C. papaya, Eugenia sp., Citrus sp., P. guajava and $A$. occidentale; Belem do Sao Francisco-Pernambuco, November 1978, on $R$. communis; Sousa-Paraiba, January, March, November 1979, on Citrus sp., unknown Rubiaceae, A. occidentale, Gossypium sp., Mangifera indica, Vigna unguiculata, Codiaeum sp., Jatropha gossypifolia, Spondias sp., C. papaya, P. guajava, A. muricata and unknown Gramineae; Xique-Xique-Bahia, January, March 1979, on Phytolacca dioica, Zea mays, Gossypium sp. and Zizyphus joazeiro; Barreiras-Bahia, January 1979, on Z. joazeiro, Physalis sp. near neesiaka and unknown Euphorbiaceae; Sao Desiderio-Bahia, January 1979, on C. papaya; Juazeiro-Bahia, February, August 1979, on Citrus sp. and Vitis vinifera; Irece-Bahia, February 1979, on Gossypium sp., C. papaya, M. indica, Persea sp. and Anona squamosa; Ouricuri-Pernambuco, January and March 1980, on Z. joazeiro and Anona squamosa; Sento Se-Bahia, January and February 1980, on Citrullus vulgaris, $P$. sp. near neesiana and Capsicum annum; Brejo Santo-Ceara, January 1980, on P. guajava; Araripina-Pernambuco, January 1980, on $A$. squamosa and Citrus sp.; Senhor do Bonfim-Bahia, March 1980, on Terminalia catappa; Ipubi-Pernambuco, April 1980, on Citrus sp. and Gossypium sp.

This species was found in association with Eutetranychus banksi, Tetranychus mexicanus, Tetranychus neocaledonicus, Tetranychus bastosi, Atrichoproctus uncinatus Flechtmann, Mononychellus planki, Oligonychus mangiferus, Tetranychus desertorum (Tetranychidae); Aculops lycopersici (Eriophyidae); Polyphagotarsonemus latus (Banks) (Tarsonemidae); and Brevipalpus phoenicis (Tenuipalpidae). Most common association seems to be with lightly webbing mites.

Previous records: Argentina (Chant, 1959), Nicaragua, El Salvador (Chant \& Baker, 1965), Paraguay (Denmark \& Muma, 1970b), Colombia (Denmark \& Muma, 1972; Moraes et al., 1982), Brazil (Denmark \& Muma, 1973; Farias et al., 1981) and Guatemala (McMurtry, 1983).

\section{Euseius ho DeLeon}

Amblyseius (Euseius) ho DeLeon, 1965a:125

Euseius ho, Denmark \& Muma, 1973:262

The specimens collected fit the description of $E$. ho, except for the somewhat shorter $\mathrm{Z}_{5}$ and macroseta of GeIV. The range of the measurements of 4 individuals collected, followed in parentheses, by our measurements of the holotype are: dorsal shield length 300-308 (329), width 190-211 (235), j1 26-29 (28), j3 16-24 (24), j4 8 (8), j5 8-11 (7), j6 11-12 (10), J2 12 (8), J5 5-6 (5), z2 11-16 (11), z4 14-22 (12), z5 8-11 (7), Z1 11-12 (8), Z4 11-12 (10), Z5 52 (58), s4 23-30 (22), S 2 13-16 (12), S4 14-16 (14), S5 17-18 (13), r3 16-18 (14), R 1 11-12 (10), SgeI 23-25 (24), $\mathrm{S}_{\mathrm{geII}}$ 22-28 (26), SgeIII 23-29 (30), S SeIV 31-36 (43), StiIV 26-29 (28), $\mathrm{S}_{\mathrm{tIV}} 48-50$ (50).

Records: Petrolina-Pernambuco, October 1978, on Solanum lycopersicum; Saude-Bahia, March 1980, on Solanum sp.

Previous records: Puerto Rico (DeLeon, 1965a; Denmark \& Muma, 1975), Brazil (Denmark \& Muma, 1973) and Jamaica (Denmark \& Muma, 1978). 


\section{Euseius sibelius (DeLeon)}

Amblyseius (Typhlodromalus) sibelius DeLeon, 1962:21

Euseius sibelius, Muma et al., 1970:98; Denmark \& Muma, 1973:262; Moraes et al., 1982:19

Euseius subalatus DeLeon, 1965a:127 (synonymy, according to Muma et al., 1970)

Individuals of this species collected in different locations showed only minor differences in setal lengths. All of them agree well with the original description.

Records: Petrolina-Pernambuco, September, October and November 1978, on Solanum americanum, Psidium guajava and Ficus sp.; Belem do Sao Francisco-Pernambuco, November 1978, on Lantana camara; Barreiras-Bahia, January 1979, on Terminalia catappa; Xique-Xique-Bahia, March 1979, on Zizyphus joazeiro; Ouricuri-Pernambuco, January, April and May 1980, on T. catappa and unknown Leguminosae; Saude-Bahia, March 1980, on T. catappa; Senhor do Bonfim-Bahia, March 1980, on T. catappa; Ipubi-Pernambuco, April 1980, on Sida sp.; Sousa-Paraiba, May 1980, on Cassia sp., Astronium urundeuva and Jatropha sp.

A. sibelius was found associated with Tetranychus evansi, Oligonychus sp., Oligonychus mangiferus, Mononychellus planki and Tetranychus bastosi (Tetranychidae).

Previous records: U.S.A. (DeLeon, 1962; Muma et al., 1970), Puerto Rico (DeLeon, 1965; Denmark \& Muma, 1975); Brazil (Denmark \& Muma, 1973; Farias et al., 1981), Jamaica (Denmark \& Muma, 1978) and El Salvador (Denmark \& Andrews, 1981).

\section{Euseius sp. near vivax (Chant \& Baker)}

Amblyseius vivax Chant \& Baker, 1965:23

Euseius vivax, Denmark \& Muma, 1973:260

The individuals collected are very similar to E. vivax. However, the dorsal shield is more heavily sclerotized than in the typical E. vivax from Central America. Also, $\mathrm{r}_{3}$ is present on dorsal shield (rare in Central America specimens of $E$. vivax), which presents a rather jagged margin near $\mathrm{R}_{1}$. The range of the measurements of 5 adult females are as follows: dorsal shield length 301-322, width 174-226, j1 31-34, j3 32-36, j4 17-21, j5 $17-19$, j6 16-19, J2 17-21, J 5 5-6, z2 25-29, z4 32-36, z5 16-18, Z 1 16-19, Z4 19-23, Z5 46-60, s4 40-46, S2 19-22, S4 19-23, S5 21-27, r3 17-19, R1 14-16, SgeIV 47-54, StiIV 33-40, StIV 63-74.

Records: Xique-Xique-Bahia, January 1979, on Phytolacca dioica; Sousa-Paraiba, March and November 1979, on unknown tree, on Spondias sp. and on Aspidosperma pyrifolium; Brejo Santo-Ceara, January 1980, on Prosopis sp.

Previous records of E. vivax: Costa Rica, El Salvador, Nicaragua (Chant \& Baker, 1965), Brazil (Denmark \& Muma, 1973) and Guatemala (McMurtry, 1983).

\section{Euseius unisetus Moraes \& McMurtry, n.sp.}

(Figs. 11-14)

DIAGNOSIS-This species is very similar to Euseius sibelius (DeLeon), from which it can be distinguished by having setae $\mathrm{r}_{3}$ and $\mathrm{R}_{1}$ on the interscutal membrane rather than on the dorsal shield. E. unisetus is also distinguished from all other species of Euseius by having distinct macrosetae only on tarsus of leg IV.

FEMALE-Dorsal shield imbricate, with 7 pairs of pores. The average measurements (with ranges) of 3 adults are: length 269 (262-276), width 165 (158-173), j1 16 (16-17), j3 18, j4 15 (14-16), j5 16 (16-17), j6 18 (17-19), $\mathrm{J}_{2} 19$ (18-20), J5 6 (6-7), z2 20 (19-22), z4 25 (24-26), z5 19, Z 20 (19-22), Z4 20 (18-22), Z5 48 (46-49), s4 27 (26-28), S 23 (22-25), S4 21 (20-22), S5 21 (20-22), r 327 (26-28), R 1 17, StIV 20. All dorsal shield setae setaceous,

Fig. 11-14-Euseius unisetus n. sp., 11 - female dorsal shield; 12 - female posterior ventral surface; 13 - spermatheca; 14 - female chelicera. 


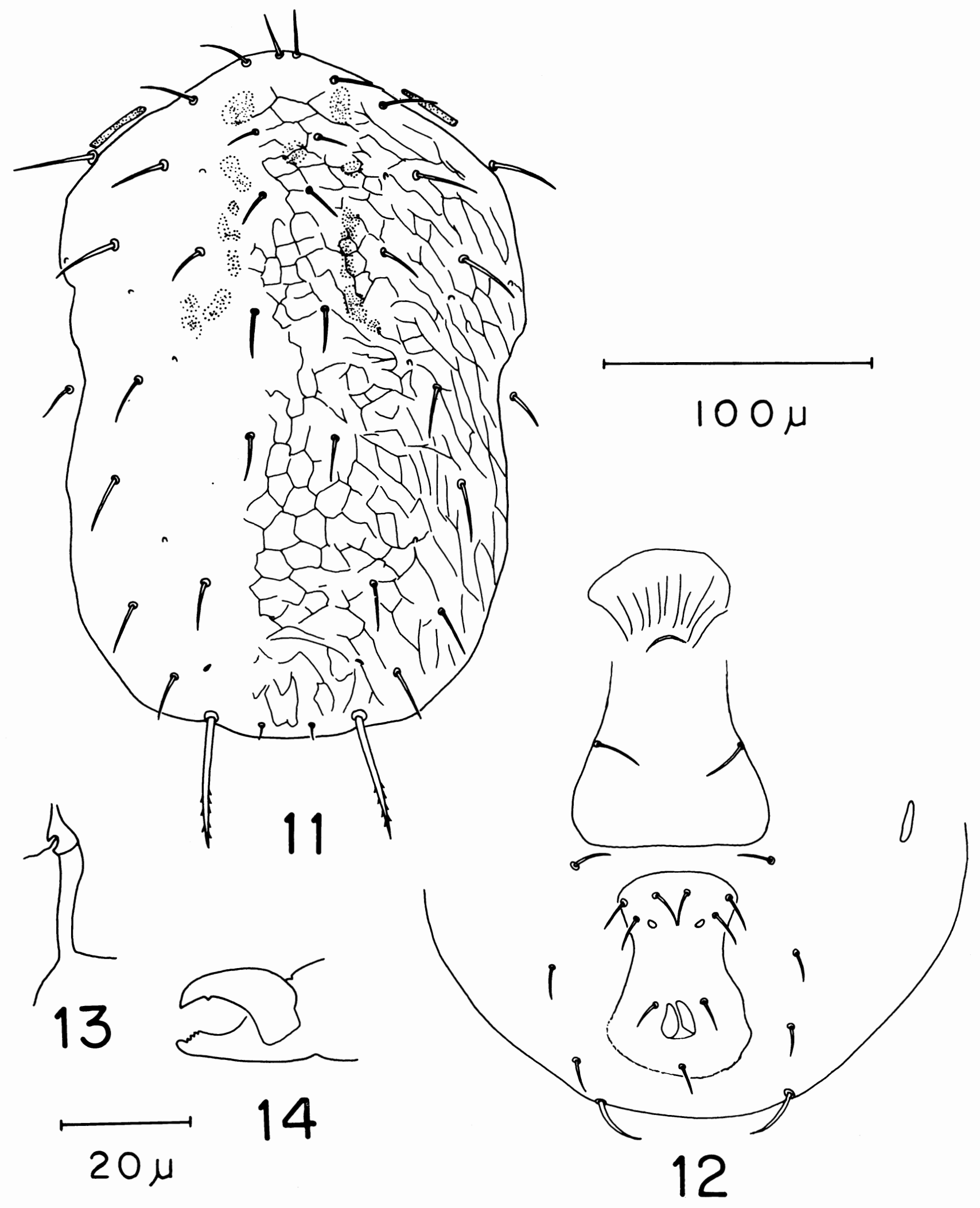


except for $Z_{5}$, which are serrate. Sternal shield indistinguishable. Ventrianal shield length 79 (78-82), greatest width near anterior margin 36, with 3 pairs of setae and a pair of pores. Movable digit of chelicera with 1 tooth; fixed digit with 4 teeth. Each digit 22 uu long. GeII $2-2-2 / 0-1$; GeIII $1-2 / 1-2 / 0-1$. Spermatheca tubular.

MALE-Unknown.

LOCALITY AND TYPE MATERIAL-Holotype-female, from unknown Leguminosae, OuricuriPernambuco, April 25, 1980 (G. J. Moraes), deposited in CPATSA/EMBRAPA.

Paratypes: 2 females, same data as holotype, deposited in UCR.

Typhlodromus annectens DeLeon

Typhlodromus annectens DeLeon, 1958:75

Galendromus annectens, Muma, 1961:298 and 1963:20; Muma et al. 1970:135; Denmark \& Muma, 1973:274; Farias et al., 1981:316; Moraes et al., 1982:21

The peritreme of the females collected is ca. 96 uu long, extending only to $\mathrm{z}_{3}-\mathrm{z} 4$, whereas the peritreme of the specimens from Florida (type-locality) is longer, extending to $z_{2}-z_{3}$, as redescribed by Muma (1963). However, the peritreme of males extends to z4-s4, agreeing with the description given by Muma (1963). Otherwise, the specimens collected in northeastern Brazil agree with the original description of the species.

Records: Ouricuri-Pernambuco, March and April 1980, on Sida sp. and on unknown Leguminosae; Ipubi-Pernambuco, April 1980, on Sida sp.

Previous Records: U.S.A. (DeLeon, 1958; Muma et al., 1970), Mexico (DeLeon, 1959), Brazil (Denmark \& Muma, 1973; Farias et al., 1981), Puerto Rico (Denmark \& Muma, 1975), Jamaica (Denmark \& Muma, 1978) and Colombia (Moraes et al., 1982).

\section{Typhlodromus subtropicus (Muma \& Denmark)}

Typhlodromina subtropica Muma \& Denmark, 1969:412; Muma et al., 1970:132

Only one individual (female) was found. The locality where this specimen was found has a distinct microclimate within the semi-arid tropics of northeastern Brazil, with a relatively high average annual rainfall of about $811 \mathrm{~mm}$. No data on setal lengths were found in the literature. The measurements of the female collected, followed, in parentheses, by the measurements of the holotype are: dorsal shield length 352 (348), width 271 (269), j1 19 (broken), j3 34 (40), j4 22 (36), j5 34 (36), j6 35 (40), J2 47 (47), J5 11 (13), z2 26 (32), z3 35 (36), z4 44 (49), z5 33 (36), Z 462 (64), Z5 57 (42), s4 43 (53), s6 55 (60), S5 56 (57), r3 30 (28), $\mathrm{R}_{1} 18$ (21). No distinguishable macrosetae are present on the legs.

Record: Senhor do Bonfim-Bahia, March 1980, on Terminalia catappa.

Previous records: U.S.A. (Muma \& Denmark, 1969; Muma et al., 1970), Galapagos Islands (Muma \& Denmark, 1969), Jamaica (Denmark \& Muma, 1978).

\section{Typhlodromus paraevectus Moraes \& McMurtry, n. sp.}

(Figs. 15-20)

DIAGNOSIS-This species is similar to Typhlodromus (= Mumaseius) evectus (Schuster), from which it differs by having thinner and sharp-tipped dorsal shield setae. Also, T. paraevectus has a distinctly knobbed macroseta on tarsus IV.

FEMALE-Dorsal shield strongly reticulated, with at least 4 pairs of large pores. The average measurements (with ranges) of 4 adults are as follows: dorsal shield length 298 (293-307), width 172 (163-178), j1 21 


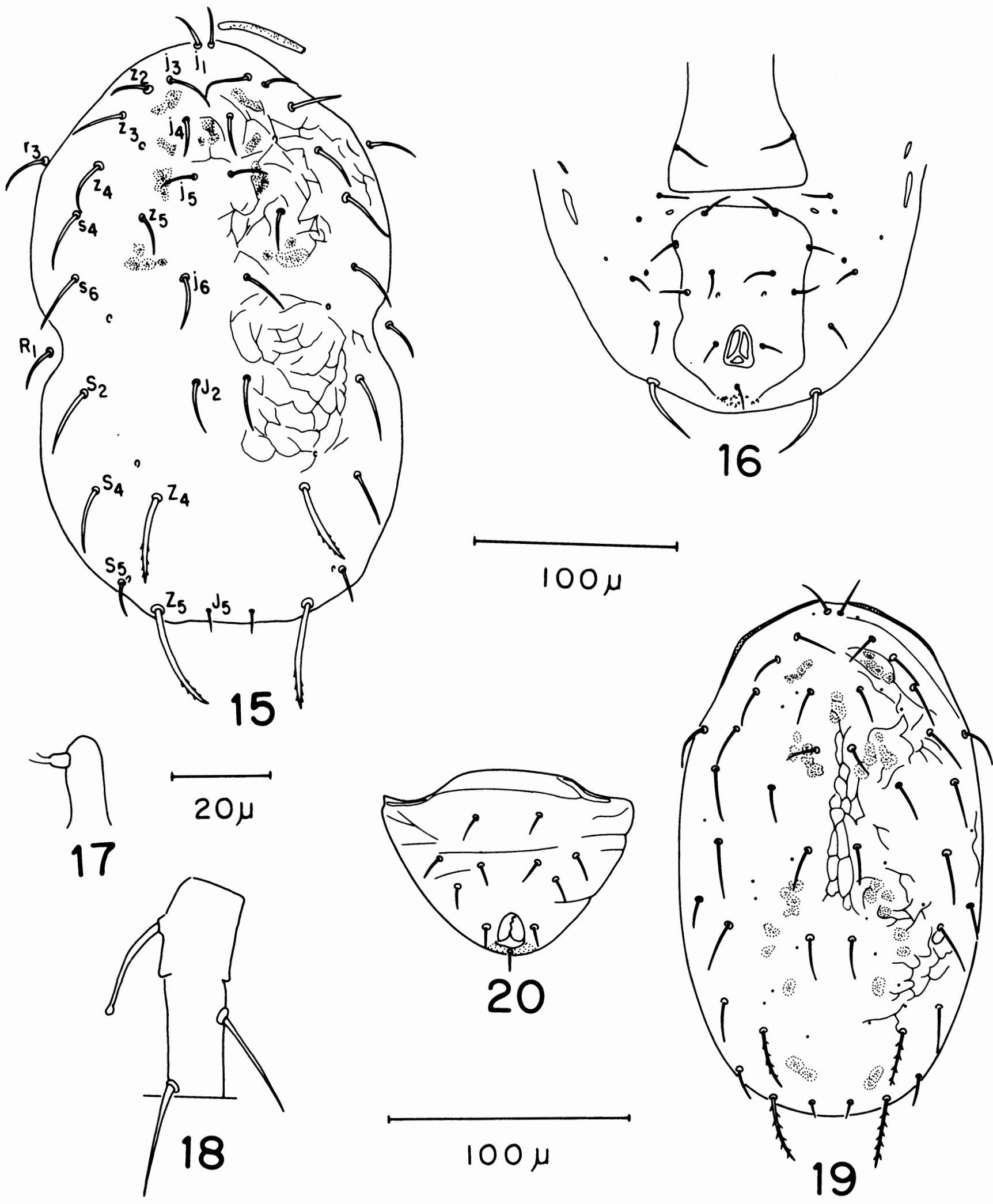

Fig. 15-20-Typhlodromus paraevectus n. sp., 15 - female dorsal shield; 16 - female posterior ventral surface; 17 - spermatheca; 18 - female tarsus IV; 19 - male dorsal shield; 20 - male ventrianal shield. 
(20-22), j3 27 (25-29), j4 22 (19-24), j5 20 (18-22), j6 26 (22-28), J2 29 (28-31), J5 7 (6-8), z2 23 (22-23), z3 26 (25-28), z4 27 (26-29), z5 22 (20-24), Z4 41 (38-43), Z5 48 (46-50), s4 30 (28-31), s6 32 (30-32), S2 34 (31-36), S4 33 (31-36), S5 20 (18-22), r3 26 (23-28), $\mathrm{R}_{1} 25$ (24-26), StIV 22 (22-23). All dorsal setae are sharp-tipped. $Z_{4}$ and $Z_{5}$ serrate. Macroseta of tarsus IV is knobbed. Sternal shield indistinct. Ventrianal shield smooth, length 97 (94-100), greatest width near anterior margin 67 (66-68); 4 pairs of preanal setae and a pair of pores. GeII $2-2-2 / 0-1$, GeIII $1-2 / 1-2 / 0-1$. Movable and fixed digits of chelicera 24 and 23 uu long, respectively. Spermatheca saccular, with atrium subapical.

MALE-Dorsal shield reticulated. The measurements of 3 adults (with ranges) are as follows: dorsal shield length 226 (223-228), width 142 (134-151), j1 16, j320, j4 17 (16-18), j5 16, j6 19, J2 20 (18-20), J5 8 (7-8), z2 18 (17-19), z3 21 (20-22), z4 22 (20-23), z5 18, Z4 27 (26-28), Z5 33 (27-36), s4 24 (23-24), s6 24, S2 24 (24-25), S4 20 (19-22), S5 14 (13-16), r3 22 (20-24), $R_{1} 19$ (18-19), StIV 19. Shape of dorsal shield setae and macrosetae, same as in female. Ventrianal shield length 87 (84-90), greatest width 117 , with 4 pairs of preanal setae.

COMMENTS-an examination of the holotype of $M$. evectus showed the presence of a short (19 uu) rodshaped macroseta on taIV and a pair of finely punctated bands along the margin of the ventrianal shield (muscle scars?) at the anus level, very similar to the punctated area behind the anus. These bands are somewhat less evident in T. paravectus. Specimens collected by the second author in June 1978, in Lima, Peru, fit the description of $T$. paraevectus, except for having a blunt-tipped macroseta on tarsus IV.

LOCALITY AND TYPE MATERIAL-Holotype-female, from Lantana camara, PetrolinaPernambuco, November 28, 1978 (G. J. Moraes), deposited in CPATSA/EMBRAPA,

Allotype-male and Paratypes - 3 females and 2 males, same data as holotype, deposited in CPATSA/ EMBRAPA, UCR and USNM.

\section{Phytoseius guianensis DeLeon}

Phytoseius guianensis DeLeon, 1965b:18; Denmark, 1966:23; Denmark \& Muma, 1973:269. the species.

The measurements of the specimens collected are very similar to those given in the original description of

This was a very common species in the areas visited.

Records: Petrolina-Pernambuco, September, October and November 1978 and February 1979, on Lantana camara, Solanum americanum, Lycopersicum esculentum and on unknown Malvaceae; Belem do Sao Francisco-Pernambuco, November 1978, on L. camara; Sousa-Paraiba, January 1979 and May 1980, on Gossypium sp. and Astronium urundeuva; Xique-Xique-Bahia, February and March 1979, on Gossypium sp.; Brejo Santo - Ceara, January 1980, on Turnera sp.; Saude-Bahia, March 1980, on unknown Malvaceae; OuricuriPernambuco, May 1980, on unknown Malvaceae.

This species was found most commonly on plants with leaves having hairy ventral surfaces, associated with Tetranychus evansi, Mononychellus planki and Tetranychus bastosi (Tetranychidae); Brevipalpus phoenicis (Tenuipalpidae); Eriophyes lantanae Cook and Aculops lycopersici (Eriophyidae).

Previous Records: Guiana (DeLeon, 1965b); Brazil (Denmark \& Muma, 1973).

Phytoseius pernambucanus Moraes \& McMurtry, n.sp.

(Figs. 21-26)

DIAGNOSIS-Adult females of this species are distinguished from the closely related Phytoseius guianensis DeLeon and Phytoseius rhabdifer DeLeon by the thicker, blunter j1, j3, z2 to $\mathrm{z}_{4}, \mathrm{~s}_{4}$ and $\mathrm{s}_{6}$ setae. It also has shorter $\mathrm{j}_{4}$ to $\mathrm{j}_{6}$ and $\mathrm{J}_{2}$, and a pair of medium size pores near $\mathrm{j}_{4}$. It also differs from those species by lacking a pair of pores on the ventrianal shield. The spermatheca of $P$. pernambucanus has a longer cervix than in $P$. rhabdifer and a distinct atrium, in which it differs from $P$. guianensis. 

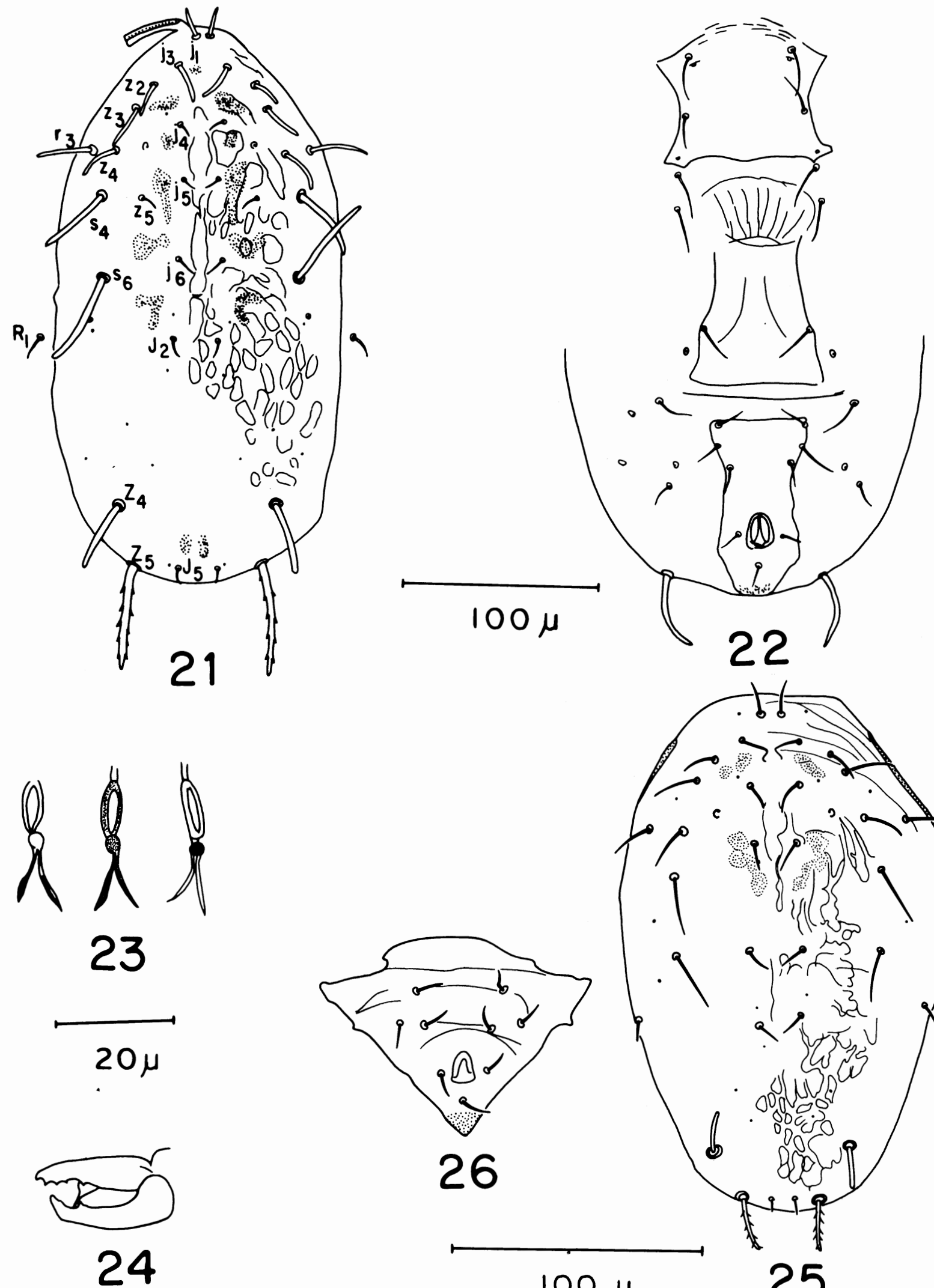
FEMALE-Dorsal shield rugose, with 11 pairs of pores. The average measurements (with ranges) for 9 adults are as follows: dorsal shield length 270 (259-288), width 131 (125-139), j1 16 (14-18), j3 20 (18-22), j4 11 (10-12), j5 10 (10-11), j6 10 (10-12), J2 10 (8-11), J5 6 (5-7), z2 15 (13-18), z3 22 (19-24), z4 23 (22-24), z5 10 (8-11), $\mathrm{Z}_{4} 35$ (32-38), Z5 56 (50-60), s4 35 (32-37), s6 43 (38-47), r3 27 (24-31), $\mathrm{R}_{1} 14$ (12-16), StIV 18 (17-19). All of the dorsal shield setae, except for $\mathrm{j}_{4}$ to $\mathrm{j}_{6}, \mathrm{~J}_{2}, \mathrm{~J}_{5}$ and $\mathrm{z5}$, are thick and blunt-tipped. $\mathrm{Z}_{5}$ serrate. $\mathrm{S}_{\mathrm{tIV}}$ is blunt-tipped. Sternal shield with 2 pairs of sternal setae and 2 pairs of pores. Third and fourth pairs of sternal setae on membrane. Ventrianal shield length 86 (70-90), greatest width near anterior margin 45 (40-48), with 3 pairs of preanal setae and no visible pores. GeII $2-2-2 / 0-1$; GeIII $1-2-2 / 0-1$. Spermatheca elongate, with flared base; with distinct atrium and broad major duct. Fixed digit of chelicera with 4 teeth; movable digit with 1 tooth. Each digit 20 uu long.

MALE-Dorsal shield rugose, with at least 10 pairs of pores. The average measurements (with ranges) of 2 adults are as follows: dorsal shield length 218 (216-220), width 115 (110-120), j1 13, j3 16, j4 11 (10-12), j5 11, j6 $11, \mathrm{~J}_{2}$ 9, J5 5, z2 13 (11-15), z3 18, z4 15 (12-18), z5 13, Z4 18 (16-20), Z5 23, s4 26, s6 23 (22-25), r3 20 (19-20), R1 $10(10-11)$, $S_{\text {tIV }} 16$. Except for $Z_{4}$ and $Z_{5}$, all setae setaceous. $Z_{5}$ serrate. $S_{t} I V$ knobbed. Ventrianal shield length 84 , greatest width 118 (115-120), with 3 pairs of preanal setae and no visible pores.

LOCALITY AND TYPE MATERIAL-Holotype female, from Solanum americanum, associated with Tetranychus evansi, Petrolina-Pernambuco, October 4, 1978 (G. J. Moraes), deposited in CPATSA/ EMBRAPA.

PARATYPES-4 females, same data as holotype; 3 females and 2 males, from Aspidosperma pyrifolia, Sousa-Paraiba, May 20, 1980 (G. J. Moraes); and 2 females from Ficus carica, Petrolina-Pernambuco, November 13, 1978 (G. J. Moraes), deposited in CPATSA/EMBRAPA, UCR and USNM.

\section{ACKNOWLEDGEMENTS}

To H. A. Denmark, Florida Department of Agriculture and Consumer Services, Gainesville, Florida, U.S.A., for his help and advice in species determination and for loans of specimens. To J. L. S. de Lima, CPATSA/EMBRAPA, for the identification of many of the host plants.

\section{LITERATURE CITED}

Chant, D. A. (1959). Phytoseiid mites (Acarina: Phytoseiidae). Part I. Bionomics of seven species in southeastern England. Part II. A taxonomic review of the family Phytoseiidae, with descriptions of 38 new species. Canad. Entomol. 91, Suppl. 12: 1-166.

Chant, D.A. (1965). Generic concepts in the family Phytoseiidae (Acarina: Mesostigmata). Canad. Entomol. 97: 351-374.

Chant, D. A., and E. W. Baker. (1965). The Phytoseiidae (Acarina) of Central America. Mems. Entomol. Soc. Canad. 41: 1-56.

Collyer, E. (1964). The occurence of some mites of the family Phytoseiidae in New Zealand, and the descriptions of seven new species. Acarologia 6: 632-646.

DeLeon, D. (1958). Four new Typhlodromus from southern Florida. Fla. Entomol. 41: 73-76.

DeLeon, D. (1959). The genus Typhlodromus in Mexico (Acarina: Phytoseiidae). Fla. Entomol. 42: 123-129.

DeLeon, D. (1961). Eight new Amblyseius from Mexico with collection notes on two other species (Acarina: Phytoseiidae). Fla. Entomol. 44: 85-91.

DeLeon, D. (1962). Twenty-three new phytoseiids, mostly from southeastern United States (Acarina: Phytoseiidae). Fla. Entomol. 45: 11-27.

DeLeon, D. (1965a). Phytoseiid mites from Puerto Rico with descriptions of new species (Acarina: Mesostigmata). Fla. Entomol. 48: 121-131.

DeLeon, D. (1965b). Ten new species of Phytoseius (Pennaseius) from Mexico, Trinidad and the British Guyana with a key to species (Acarina: Phytoseiidae). Entomol. News 76: 11-21.

DeLeon, D. (1966). Phytoseiidae of British Guyana with keys to species (Acarina; Mesostigmata). In Studies on the fauna of Suriname and other Guyanas. 8: 81-102.

DeLeon, D. (1967). Some mites of the Caribbean area; Part I. Acarina on plants in Trinidad, West Indies. Allen Press, Inc., pp. 1-66. 
Denmark, H. A. (1965). Four new Phytoseiidae (Acarina: Mesostigmata) from Florida. Fla. Entomol. 48: 89-95.

Denmark, H. A. (1966). Revision of the genus Phytoseius Ribaga, 1904 (Acarina: Phytoseiidae). Fla. Dept. Agric. Div. Plant Ind. Bull. 6: 105 pp.

Denmark, H. A., and K. L. Andrews. (1981). Phytoseiidae of El Salvador, Central America (Acarina: Mesostigmata). Fla. Entomol. 64: 147-158.

Denmark, H. A., and M. H. Muma. (1970a). Ricoseius loxocheles (DeLeon) (Acarina: Phytoseiidae). Fla. , Entomol. 53: 119-121.

Denmark, H. A., and M. H. Muma. (1970b). Some phytoseiid mites of Paraguay (Phytoseiidae: Acarina). Fla. , Entomol. 53: 219-227.

Denmark, H. A., and M. H. Muma. (1972). Some Phytoseiidae of Colombia (Acarina: Phytoseiidae). Fla. Entomol. 55: 19-29.

Denmark, H. A., and M. H. Muma. (1973). Phytoseiid mites of Brazil (Acarina: Phytoseiidae). Rev. Brasil. Biol. 33: 235-276.

Denmark, H. A., and M. H. Muma. (1975). The Phytoseiidae (Acarina: Mesostigmata) of Puerto Rico. Puerto Rico J. Agric. 59: 279-304.

Denmark, H. A., and M. H. Muma. (1978). Phytoseiidae of Jamaica, an annotated list (Acari: Mesostigmata). Intl. J. Acar. 4: 1-22.

Ehara, S. (1966). Some mites associated with plants in the state of Sao Paulo, Brazil, with a list of plant mites of South America. Jap. J. Zool. 15: 129-150.

Elbanhawy, E. M. (1975). New Amblyseius mite from Brazil. Rev. brasil. Biol. 35: 549-552.

Elbanhawy, E. M. (1976). A new predaceous mite of the genus Typhlodromus Scheuten from Brazil. Rev. Brasil. Biol. 36: 531-534.

Elbanhawy, E. M. (1978). Description of some unknown phytoseiid mites from Brazil (Mesostigmata: Phytoseiidae). Acarologia 20: 477-484.

Farias, A. R. N., C. H. W. Flechtmann, G. J. Moraes, and J. A. McMurtry. (1981). Predadores do acaro verde da mandioca no Nordeste do Brasil. Pesquisa Agropecuaria Brasileira 16: 313-317.

Garman, P. (1958). New species belonging to the genera Amblyseius and Amblyseiopsis with keys to Amblysieus, Amblyseiopsis and Phytoseiulus. Entomol. Soc. Amer., Ann. 51: 69-79.

Garman, P., and E. A. McGregor. (1956). Four new predaceous mites (Acarina: Phytoseiidae). Bull. So. Calif. Acad. Sci. 55: 7-13.

McMurtry, J. A. (1983). Phytoseiid mites from Guatemala, with descriptions of two new species and redefinitions of the genera Euseius, Typhloseiopsis, and the occidentalis species group (Acari: Mesostigmata). Int. J. Entomol. (In press).

Moraes, G. J., and J. V. Oliveira. (1982). Phytoseiid mites of coastal Pernambuco, in northeastern Brazil. Acarologia 23: 315-318.

Moraes, G. J., H. A. Denmark, and J. M. Guerrero. (1982). Phytoseiid mites of Colombia (Acarina: Phytoseiidae). Int. J. Acarol. 8: 15-22.

Muma, M. H. (1961). Subfamilies, genera and species of Phytoseiidae (Acarina: Mesostigmata). Bull. Fla. State Mus. 5: 267-302.

Muma, M. H. (1962). New Phytoseiidae (Acarina: Mesostigmata) from Florida. Fla. Entomol. 45: 1-10.

Muma, M. H. (1963). The genus Galendromus Muma, 1961 (Acarina: Phytoseiidae). Fla. Entomol. Suppl. 1: $15-41$.

Muma, M. H., and H. A. Denmark. (1969). The conspicua species group of Typhlodromina Muma, 1961 (Acarina: Phytoseiidae). Entomol. Soc. Amer., Ann. 62: 406-413.

Muma, M. H., H. A. Denmark, and D. DeLeon. (1970). Phytoseiidae of Florida. Fla. Dept. Agric. Cons. Serv. Div. Plant Ind. 6: 1-150.

Muma, M. H., L. J. Metz, and M. H. Farrier. (1967). New species and records of Phytoseiidae (Acarina: Mesostigmata) from North Carolina forest litter. Fla. Entomol. 50: 199-206.

Prasad, V. (1968). Amblyseius mites from Hawaii. Entomol. Soc. Amer., Ann. 61: 1514-1521.

Rowell, H. J., D. A. Chant, and R. I. C. Hansell. (1978). The determination of setal homologies and setal patterns on the dorsal shield in the family Phytoseiidae (Acarina: Mesostigmata). Can. Entomol. 110: 859-876.

Schicha, E. (1981). A new species of Amblyseius (Acarina: Phytoseiidae) from Australia compared with ten closely related species from Asia, America and Africa. Int. J. Acarol. 7: 203-216.

Schuster, R. O., and A. E. Pritchard. (1963). Phytoseiid mites of California. Hilgardia 34: 191-285.

Specht, H. B. (1968). Phytoseiidae (Acarina: Mesostigmata) in the New Jersey apple orchard environment with descriptions of spermathecae and three new species. Can. Entomol. 100: 673-692. 
Tuttle, D. M., and M. H. Muma. (1973). Phytoseiidae (Acarina: Mesostigmata) inhabiting agricultural and other plants in Arizona. Agric. Exp. Sta., Univ. Arizona, Tech. Bull 208, 55 pp. 